\title{
Extraction and purification of protease from Aspergillus niger isolation
}

\begin{abstract}
Growth Aspergillus niger on solid state fermentation media for produce protease. The best condition for protease production in the moisture is 1:30 and incubation at $40^{\circ} \mathrm{C}$ for 8 day at $\mathrm{PH} 8$. Inoculation with $2.2 \times 10^{4}$ cell $/ \mathrm{ml}$ of fungal media containing, different nitrogen sources the peptone the bast. Protease was precipitated from production media by $70 \%$ saturation of ammonium sulphat with $3.5 \mathrm{U} / \mathrm{mg}$ protein specific activities, the final purification in DEAE-cellulose 9.8 fold of purification and 0.188 yield.
\end{abstract}

Keywords: Aspergillus niger, protease, purification, enzyme
Volume 6 Issue 2 - 2018

\author{
Mais E Ahmed \\ Department of Biology, University of Baghdad, Iraq
}

Correspondence: Mais EAhmed, Department of Biology, College of science, University of Baghdad, Iraq, Email mais.e.mahmood@gmail.com

Received: February 19, 2018 | Published: March 15, 2018

\section{Introduction}

Industrial enzymes have seen spectacular rise there production in the last 3 decades. The growth of industrial market has expended to nearly 85 enzymes, which are correctly in commercial production with the discovery of variety of new and more active enzyme. Protease represent one of three largest group of industrial enzyme and account for about $60 \%$ of the total worldwide sell of enzymes. ${ }^{1}$ Proteases are the single class of enzymes which occupy a pivotal position with respect to their applications in both physical and commercial fields. ${ }^{2}$ Proteolytic enzymes catalyzed the cleavage of peptide bonds in their protease, proteolytic enzymes can be classified as acidic ${ }^{3}$ natural and alkaline protease with the regard to their $\mathrm{PH}$ working range. Natural and alkaline proteases hold great potential for application in the detergent and leather tanning industrial due to increasing trend in developing environment friendly technologist. ${ }^{4}$ Alkaline proteases have numerous applications in food industry. ${ }^{5}$ Silver recovery from $\mathrm{x}$-ray film ${ }^{6}$ and several bioremediation processes. Plants, animals and microbial sources are employed for protease production. Microbes serve as the preferred source of proteases because of their rapid growth the limited space required for their cultivation, and the ease which they can be genetically manipulation to general new enzymes with prosperities $^{7}$ microbial extra cellular protease are important enzyme and mainly used in detergent to facilitate the release of protein strain such as blood, milk, egg, meat and food and leather industrial and is an important tool in studying the structure of protein and peptide. ${ }^{8,9}$ The price of commercially available enzyme which are produced mostly by submerged fermentation usually too high for biotechnology applications. An alternative technique for enzyme production is solid state fermentation. ${ }^{10}$ Solid state fermentation has some advantage compared with liquid state culture higher product yield, better product quality, cheaper, product recovery and cheaper technology. ${ }^{10}$

\section{Materials and methods}

\section{Microorganism and culture conditions}

Aspergillus niger was obtained from biology department/ college of science / Baghdad university, the organism maintained on potatodextrose agar slant at $4^{\circ} \mathrm{C}$.

\section{Preparation of culture filtrate}

Wheat bran under the conditions of solid state fermentation Erlenmeyer corucal flask of $250 \mathrm{ml}$ capacity were used containing $20 \mathrm{ml}$ of liquid media without organic source and 10 gm of dry wheat bran medium and sterilized at $21^{\circ} \mathrm{C}-15$ minutes inoculation spore suspension of organism preparation sterile distilled water and adjusted to $\left(1 \times 10^{6}\right)$ spores $/ \mathrm{ml}$. incubation was carried out $26^{\circ} \mathrm{C}$ under static conditions after 7 days the contain of the flask were filtered through Whatman No. 3 filter paper disc. Culture filtrate was centrifuged at $5000 \mathrm{~g}$ for $10 \mathrm{mins} / 4^{\circ} \mathrm{C}$ and supernatant was used as the crude enzyme.

\section{Proteins assay}

Protease activity in the culture supernatant was determined by using in the method originally described by Murachi ${ }^{11}$ and modified by Senior ${ }^{12}$ as fallowing:

Casein $(0.8 \mathrm{ml}, 0.5 \%$ and $\mathrm{PH}=8)$ was pre incubated in water bath at $37^{\circ} \mathrm{C}$ for 10 minutes. Unit of enzyme activity was defined as the amount of enzyme, which give 0.01 increase at absorbent $\mathrm{Ab}=280 \mathrm{~nm} /$ min under the assay condition. The protease activity was determinate by using this equation:

Protease activity $\mathrm{U} / \mathrm{ml}=\mathrm{Ab}$. at $280 \mathrm{~nm} / 0.001 \times 20 \mathrm{~min} . \times 0.2 \mathrm{ml}$.

One unit of protease activity was define as that amount of enzyme which librates $1 \mathrm{mg}$ equivalent of peptide fragment under the assay condition using bovine serum albumin as standard specific activity is expressed unit per mg protein.

\section{Optimization of the enzyme}

PH: The natural protease production was determined by using different PH 5,6,7,8.

Incubation period: The natural protease production was determined by using different incubation period 7, 8, 9 and 10 days.

Temperature: The influence of temperature of production of natural protease was studied by incubating media at different temperature 25 , 30,35 and $40^{\circ} \mathrm{C}$.

Nitrogen source: Nitrogen source of natural protease production was determined by using different sources (peptone, tryptone, casein and yeast extract). 
Inoculum size: The influence of inoculation represent $\left(1 \times 10^{6}\right)$ of the production of natural protease was studied by inoculation media at the different volumes $1 \times 10^{6}, 2 \times 10^{6}, 3 \times 10^{6}$ and $4 \times 10^{6}$ spores $/ \mathrm{ml}$.

\section{Purification of protease}

Purification steps inoculated ammonium sulphate precipitate optioned $60-90 \%$ saturation was developed in small amount of 0.02 M sodium sulphate puffer PH 6.8 and was dialyzed 3 times over night against the same buffer. Any sediment formed were removed by centrifugation and the supernatant was loaded on DEAE-cellulous Colum $2 \times 30 \mathrm{~cm}$ previously equilibrated with the $0.02 \mathrm{M}$ sodium phosphate buffer, PH 7 column elusion was performed by the same buffer with increase in morality form 0.02 to $0.5 \mathrm{M}$ by inoculation of $\mathrm{NaCl}$.

Protease activity was assayed at PH 6.8 and the peaks obtained were intern tested for optimum PH. Fraction showing maximum activity in the respective peak area were boiled.

\section{Results and discussion}

\section{Influence of $\mathrm{PH}$}

The maximum protease production $3.4 \mathrm{U} / \mathrm{ml}$ found at $\mathrm{PH} 7$ (Figure 1). The result clearly indicated neutrophilic of the fungus. The medium protease production by $A$. niger was observed in range $\mathrm{PH}$ 7-9. Growth and protein production cased of $\mathrm{PH} 10$ optimum $\mathrm{PH} 7$ has been reported for natural protease of $A$. niger. ${ }^{13}$

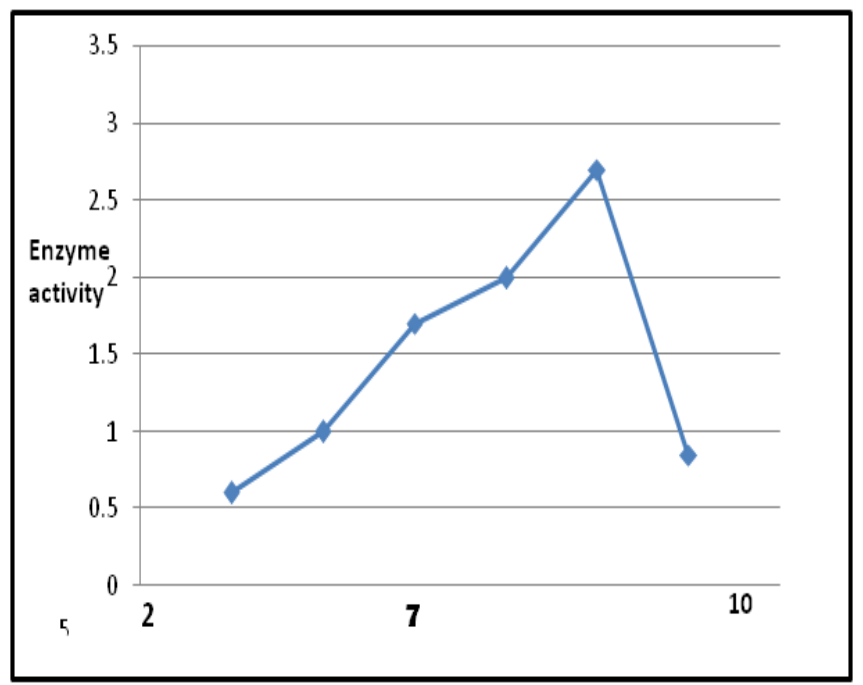

Figure I Effect of $\mathrm{PH}$ on the production of protease by A. niger.

\section{Influence of incubation period}

The maximum activity of enzyme was observed after 8 days of fermentation process (Figure 2) when the fungus grows passed the lag. Phase and the enzyme production start ${ }^{14}$ stated the A.flavus optimally produced protease after 10 days of incubation.

\section{Influence of temperature}

The protease production at different temperatures range were examined after 8 day keeping the other fermentation constant protease production increase at temperature $40^{\circ} \mathrm{C}$ maximum production of protease $4.2 \mathrm{U} / \mathrm{ml}$ obtain at $40^{\circ} \mathrm{C}$ (Figure 3 ) also found Bhanerochaete chrusosporium optimally at $25^{\circ} \mathrm{C} .{ }^{15}$ It was revealed that temperature does not only affect growth rate of organism but also exhibited marked influence on the level of protease production.

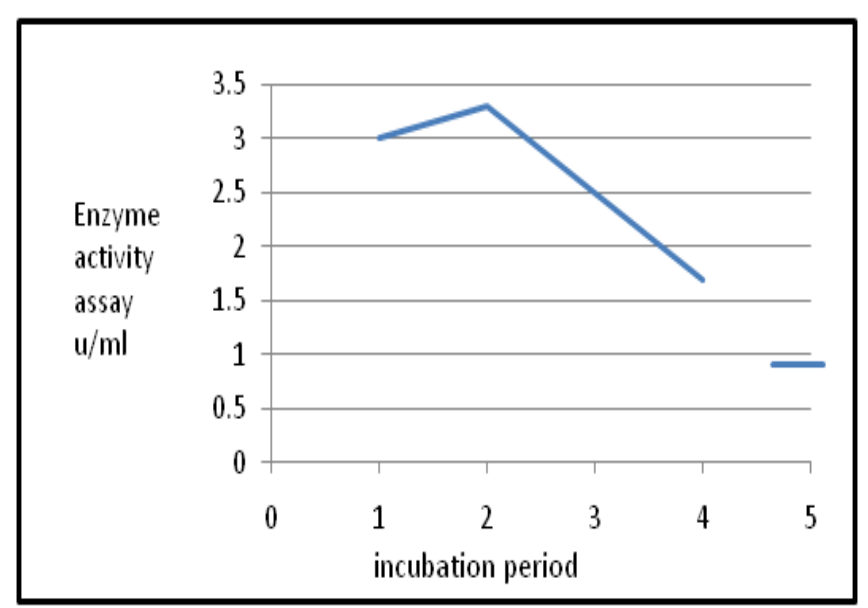

Figure 2 Effect of incubation period on the production of protease by $A$. niger.

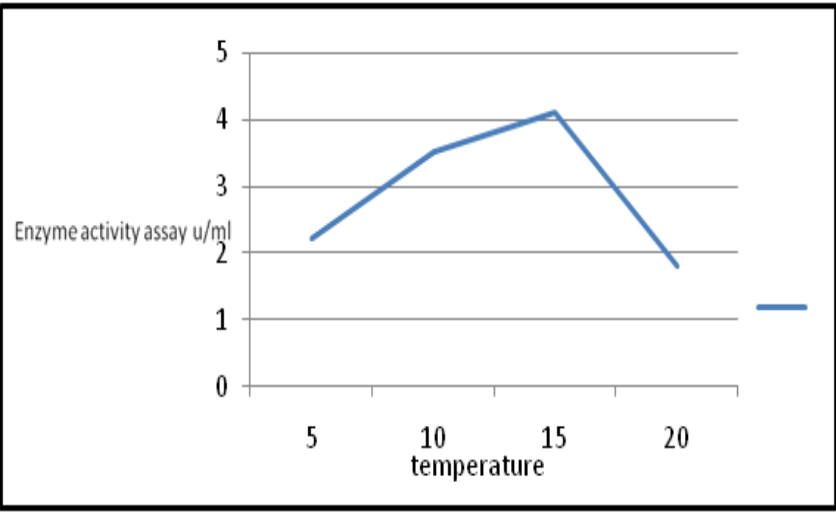

Figure 3 Effect of temperature on the production of protease by A. niger.

\section{Influence nitrogen source}

Among the various nitrogen source peptone and tryptone were found to be the most effective for protease product 5.4, $5.1 \mathrm{U} / \mathrm{ml}$ respectively (Figure 4). The mechanism that shows the formations of extracellular enzyme influenced by the visibility of precursors for protein synthesis. The effect of nitrogen source like peptone, casein,tryptone and yeast extract has reported that nitrogen source stimulated equal accumulation of protease in the culture medium of A.terreus. ${ }^{16}$

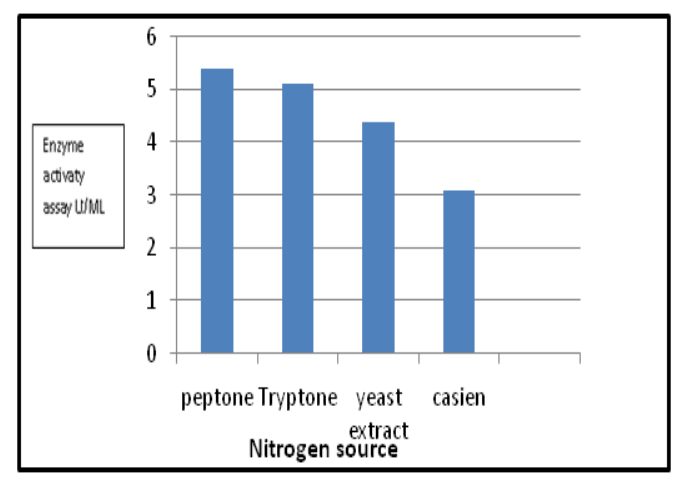

Figure 4 Effect of nitrogen source on the production of protease by A. niger. 


\section{Influence of inoculums size}

The study of the effected of inoculums size, fungus was grown at various inoculums size $\left(1 \times 10^{6}, 2 \times 10^{6}, 3 \times 10^{6}\right.$ and $4 \times 10^{6}$ spores $/ \mathrm{ml}$. using production medium containing $1 \%$ casein as the main substrate. The highest activity was observed for protease production $3.26 \mathrm{U} / \mathrm{ml}$ in $1 \times 10^{6}$ spores $/ \mathrm{ml}$ inoculums size of the spore suspension (Figure 5) in order to verify the enzyme activity, the spore concentration must be high enough to colonized the substrate particles, ${ }^{17}$ many studies however have indicated that there can be peak line in this activity over determent spore concentration.

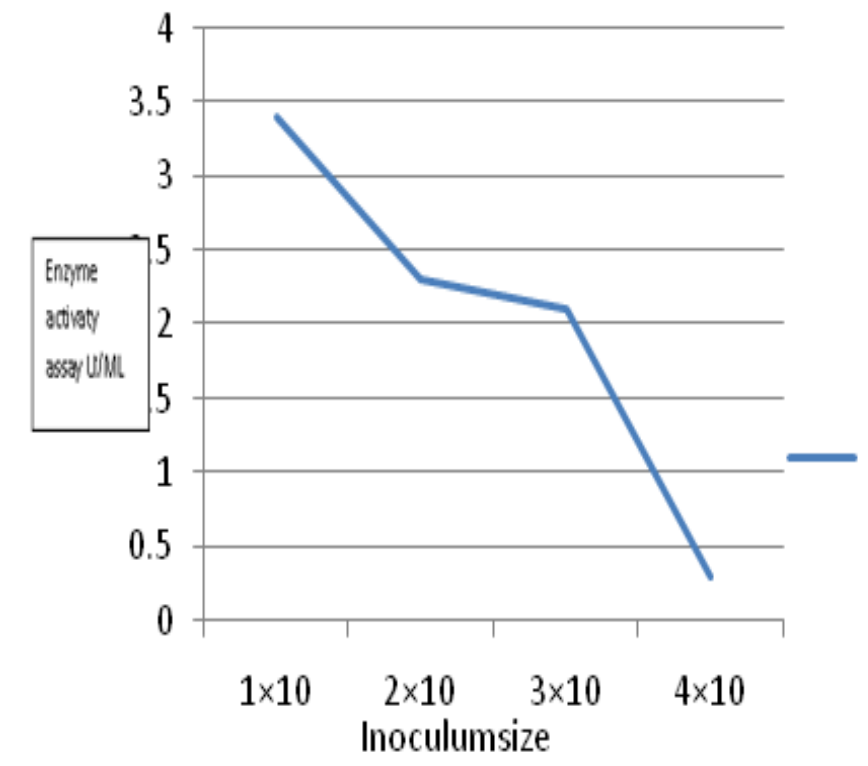

(spore/ml)

Figure 5 Effect of inoculums size on the production of protease by A. niger.

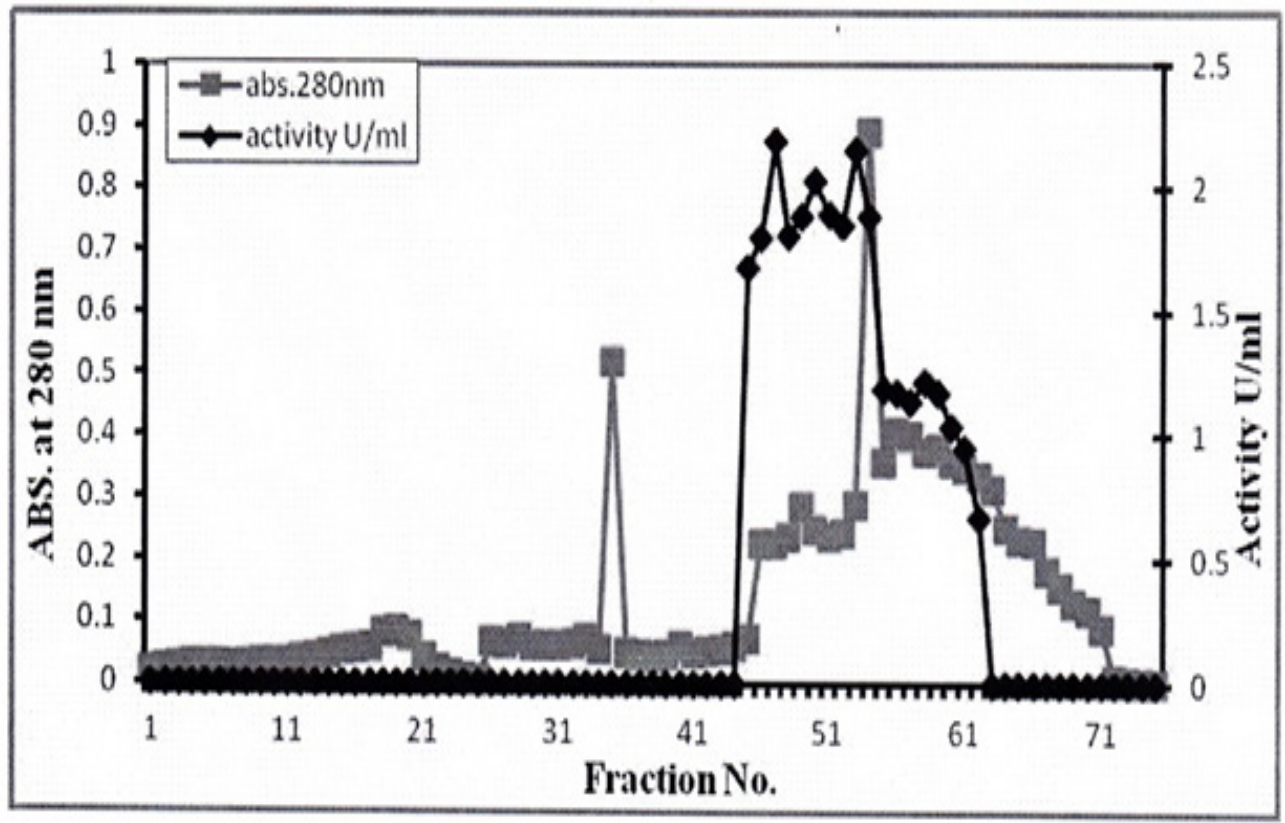

Figure 6 Elution profile of protease from DEAE-cellulose column chromatography. 


\section{Purifications steps}

Protease produced by A.spp was recovered in Table 1. The first step was carried out by precipitation of protein from the cell free dialysis with ammonium sulphate at the saturation level of $60 \%$. This resulted in 2.3 fold of purification of protease with yield of $9.78 \%$ of the original activity chromatography on DEAE-cellulous using liner sodium chloride ingredient the wash step and until fraction no. 41 and then start elusion step. The result showed that protease that protease was purified 8.94 fold to specific activity of $30.21 \mathrm{U} / \mathrm{mg}$ protein (Figure 6).

Table I Purification of protease from A. niger by solid state fermentation.

\begin{tabular}{|c|c|c|c|c|c|c|c|c|}
\hline Sample & Volume(ml) & Activity(U/ml) & $\begin{array}{l}\text { Protein } \\
(\mathrm{mg} / \mathrm{ml})\end{array}$ & $\begin{array}{l}\text { Specific } \\
\text { activity(u/mg) }\end{array}$ & $\begin{array}{l}\text { Total activity } \\
\text { (U/ml) }\end{array}$ & $\begin{array}{l}\text { Total protein } \\
\text { (mg) }\end{array}$ & $\begin{array}{l}\text { Yield } \\
\%\end{array}$ & Fold \\
\hline Crude extract & 400 & 3.9 & 1.17 & 3.37 & 1580 & 468 & 100 & I \\
\hline Perception $60 \%$ & 25 & 6.18 & 0.78 & 7.8 & 154.6 & 19.6 & 9.78 & 2.33 \\
\hline DEAE-cellulose & 90 & 1.57 & 0.052 & 30.2 & 141.9 & 4.68 & 0.18 & 8.94 \\
\hline
\end{tabular}

\section{Conclusion}

Purification enzyme protease by DEAE-cellulose from local isolation Aspergillus niger optimum condition produce at 2 day at $\mathrm{PH}$ 8 Inoculation with $2.2 \times 10^{4} \mathrm{cell} / \mathrm{ml}$.

\section{Acknowledgement}

None.

\section{Conflict of interest}

None.

\section{References}

1. Godfrey T, West S. Industrial enzymology. $2^{\text {nd }}$ edn. Macmillan publisher Inc: New York; 1996. 582p.

2. Rao K, Parmeela DY, Lakshmi NM. A New acidic protease from Bacillus badius. J Aqua Biol. 2007;22(1):1-6.

3. J Sharma, A Singh, R Kumar, et al. Partial Purification of an Alkaline Protease from a New Strain of Aspergillus Oryzae AWT 20 and its Enhanced Stabilization in Entrapped Ca-Alginate Beads. Internet Journal of Microbiology. 2006;2(2):1-9.

4. Aparna RM, Tanksale M, Mohini G, et al. Molecular and biotechnological aspects of microbial proteases. Microbiol Mol Biol Rev. 1998;62(3):597-635.

5. Kalsz HM. Microbiol proteinases. Adv Biochem Eng Biotechnol. 1998;36:1-65.

6. Outtrup H, Boycs CL. Microbial proteinases and biotechnology. In: Fogarty CT, Kelly K, editors. Microbial enzymes and biotechnology. Elsevier: London; 1990. p. 227-254.
7. Puri S. An alkaline protease from Bacillus spp production and potential application in detergent formulation and degumming of silk. Msc Thesis, University of Delhi: Delhi; 2001.

8. Fugiwra N, Yamamoto K, Masui A. Utilization a thermostable alkaline protease from alkalophilic thermophile for the recovery of silver from used X-ray film. J Ferment Bio Eng. 1991;72(4):306-308.

9. Rao MB, Tanksale AM, Ghateg MS, et al. Molecular and biotechnology aspects of microbial protease. Microbiol Mol Biol Rev. 1998;62(3):597-635.

10. Janolino VG, Swaisgood HE. Analysis and optimization of methods using water soluble carbodiimide for mobilization of biochemical to porous glasses. Biotechnol Bioeng. 1982;24(5):1069-1080.

11. Murachi T. Bromelain enzymes. Methods Enzymol. 1976;45:475-485.

12. Senior BW. Investigation of the types and characteristics of the proteolytic enzymes formed by diverse strains of Proteus species. J Med Microbiol. 1999;48(7):623-628.

13. Patil M, Shastri NV. Extracellular Production of Proteases by Alternaria alternata (Fr.) Keissl. J Ferment Tech. 1981;59(5):403-406.

14. Morimura S, Kida U, Sonava U. Production of protease using west water from the manufacture of shochu. J Ferment Bio Eng. 1994;77(2):183-187.

15. Mrita M, Nishi A. Isolation and partial characterization of haemagglutinins from plasmodia of Physarum polycephalum. J Gen Microbiol. 1992;138(3):619-625.

16. Coral G, Arkan B, Nald MN et al. Thermostable alkaline protease produced by Aspergillus niger strain. Annals of Microbiology. 2003;53(4):491-498.

17. Srinupapu G, Lokeswari N, Jayaraju K. Screening of neutronational parameters for the produciton of protease from Aspergillus oryza. E-Journal of Chemistry. 2007;4(2):208-215. 